\title{
ANALISIS PERBANDINGAN KINERJA KEUANGAN PERUSAHAAN PENGAKUISISI SEBELUM DAN SESUDAH AKUISISI PADA TAHUN 2016
}

\author{
Angdriani Puspita Dewi \\ Universitas Negeri Surabaya \\ angdriani.puspita@gmail.com \\ Ulil Hartono \\ Universitas Negeri Surabaya \\ ulilhartono@unesa.ac.id
}

\begin{abstract}
The expansion was one or other business strategies which every company typically do to compete in the global market. The successful acquisition was assessed based on the acquiring company's financial performance ratio between before and after the acquisition. The function of this paper to analyze the financial performance of acquiring company's who perform an acquisition in 2016 period which is proxied with the ratio finance Current Ratio (CR), Debt to Equity (DER), Debt to Asset (DAR), Return on Equity (ROE), and Return on Asset (ROA). The analytical technique used was the Paired Sample T-test for normally distributed data and the Wilcoxon Sign Rank Test for abnormally distributed data. Based on the outcome of the analysis develop that company's financial performance as intended by financial ratios are Current Ratio (CR), Debt to Equity (DER), Debt to Asset (DAR), Return on Equity (ROE), and Return on Assets (ROA) not significantly different after the acquiring considered to before the acquiring. This research proves that the acquisition strategy does not always guarantee an increase in a company's financial performance after acquiring.
\end{abstract}

Keywords: acquiring; paired sample t-test; Wilcoxon sign rank test.

\section{PENDAHULUAN}

Perubahan teknologi yang begitu pesat saat ini, semakin dipermudahkannya setiap individu mendapatkan sumber daya yang ada dan adanya globalisasi sekaligus timbulnya perdagangan bebas sehingga menyebabkan persaingan diantara perusahaan-perusahaan saat ini menjadi semakin sulit, sehingga menuntut perusahaan secara tidak langsung harus segera menggunakan strategi bisnis yang dirasa efektif dan efisien guna menghasilkan sebuah keunggulan yang kompetitif dalam persaingan saat ini (Kamaludin et al. 2015:6). Terbukanya peluang pasar global (global market) akibat dari globalisasi dan pemberlakukan Masyarakat Ekonomi ASEAN (MEA) telah memicu perubahan lingkungan pasar bisnis yang ada dan menaikkan persaingan di bisnis yang ada di semua industri termasuk di Indonesia. Perubahan tersebut mendesak setiap perusahaan untuk segera mengambil kebijakan yang tepat agar dapat memimpin persaingan demi kelangsungan bisnisnya dalam masa yang lebih panjang (Erlyene \& Musdholifah, 2019:594).

Bentuk strategi bisnis yang dapat dilakukan oleh perusahaan dalam menghadapi ketatnya persaingan usaha di pasar global adalah dengan melakukan ekspansi atau memperluas usahanya. Model dari ekspansi usaha yang dapat dijalankan perusahaan yaitu dengan menggabungkan perusahaan dengan perusahaan lain menggunakan merger atau akuisisi. Merger dan akuisisi menjadi strategi pertumbuhan bagi perusahaan berdampak dengan cepat dalam menjangkau pasar baru yang lebih luas bagi produknya tanpa harus menciptakan perusahaan dari awal. Alasan penyebab perusahaan lebih condong untuk merger dan akuisisi dibandingkan menggunakan pertumbuhan secara internal menjadi strateginya, dikarenakan merger dan akuisisi bagi perusahaan dijadikan alternatif perusahaan dalam menggapai tujuan perusahaan tanpa berusaha memulai dari awal dan dirasa sebagai jalan yang lebih cepat (Silaban, 2017:140).

Komisi Pengawas Persaingan Usaha (KPPU) mempubllikasikan banyak pengumuman merger atau akuisisi yang masuk pada tahun 2011 hingga tahun 2018 seperti yang dapat dilihat di Gambar 1. Bentuk dari strategi bisnis suatu perusahaan berupa merger dan akuisisi dapat berdampak langsung bagi merger 
dan akuisisi perusahaan. Perusahaan dikatakan sukses menjalankan merger dan akuisisi ditinjau dari dasar kinerja perusahaan sebelum dan setelah perusahaan pengakuisisi mewujudkan penggabungan usaha. Bentuk lain dari analisis yang dapat digunakan untuk menimbang keberhasilan dari merger dan akuisisi yakni menggunakan komparasi kinerja keuangan perusahan dengan periode sebelum dan setelah akuisisi (Dewi \& Suryatini, 2018:2326). Rasio yang dapat dimanfaatkan guna meninjau kinerja keuangan perusahaan yakni likuiditas (current ratio), solvabilitas (debt to equity ratio dan debt to assets ratio), dan profitabilitas (return on equity ratio dan return on assets ratio) (Nafilah \& Damayanti, 2019:193).

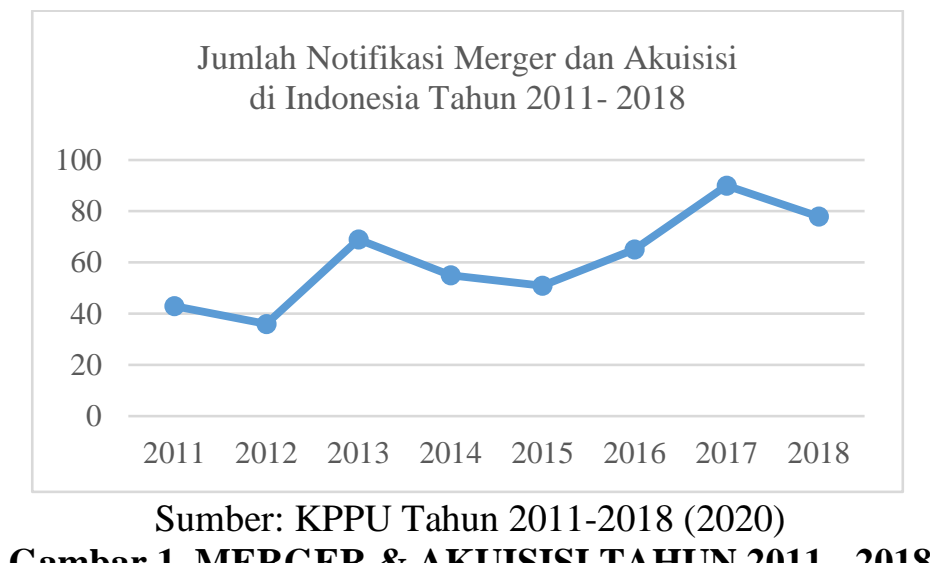

Penelitian ini bertujuan mengkaji perbedaan kinerja keuangan perusahaan pengakusisi sebelum dan sesudah melakukan akuisisi. Peneliti mengambil periode pengamatan pada tahun 2013-2019, dengan periode pengamatan 3 tahun sebelum dan sesudah akuisisi. Ketika perusahaan melakukan akuisisi, tahun dilakukannya akuisisi yaitu tahun 2016 tidak diikutkan dalam perhitungan (Hartono, 2016:649).

\section{KAJIAN PUSTAKA DAN PENGEMBANGAN HIPOTESIS}

\section{Signalling Theory}

Teori sinyal atau sering dikenal dengan signalling theory yakni teori yang menjelaskan bahwa investor menganggap perkiraan pendapatakn manajemen diakibatkan dari perubahan deviden (Brigham \& Houston, 2009:444). Laporan keuangan perusahaan mencakup dari sebagian informasi penting yang berguna bagi semua pemegang kepentingan, baik itu manajemen investor maupun stakeholder lainnya. Informasi yang didapati dari rasio likuiditas, profitabilitas maupun solvabilitas dapat menjadi sinyal bagi pihak eksternal. Nilai rasio-rasio yang baik dapat menggambarkan bahwa perusahaan memiliki kinerja yang baik pula sehingga memberikan dampak sinyal positif bagi pihak eksternal untuk menanamkan modal pada perusahaan tersebut (Pratiwi \& Damayanti, 2017:236).

\section{Ekspansi}

Salah satu bentuk strategi bisnsi dalam ekspansi perusahaan ialah penggabungan usaha yang bertujuan guna meraih kontrol atas aktiva atau operasional perusahaan-perusahaan yang hendak berintegrasi (Novaliza \& Djajanti, 2013:1). Suad dan Enny (2012:395) menyatakan ekspansi dapat terurai menjadi dua macam yakni ekspansi internal dan ekspansi eksternal. Ekspansi eksternal dapat dijalankan dengan penggabungan usaha atau pengambilalihan usaha perusahan target menggunakan cara merger atau akuisisi (Sitanggang, 2013:199).

Merger ialah peleburan dari usaha dengan usaha suatu perusahaan lain. Dengan melakukan merger perusahaan tetap menggenggam nama perusahaan dan identitas, aset dan kewajiban milik perusahaan yang target hendak dipindahkan ke perusahaan pelaku merger, di sisi lain perusahaan target hendak ditutup (Mamduh, 2013:662). Sedangkan pengertian dari akuisisi yakni bentuk peleburan dua perusahaan yakni akuisitor membeli beberapa bagian saham perusahaan target (perusahaan akan 
Angdriani Puspita Dewi \& Ulil Hartono. Analisis Perbandingan Kinerja Perusahaan Pengakuisisi Sebelum dan Sesudah Akuisisi Pada Tahun 2016

diakuisisi), penanganan manajemen dari perusahaan target beralih ke perusahaan akuisitor, selagi kedua belah pihak perusahaan masih berjalan menjadi badan hukum yang independen (Sudana 2011:246).

Menurut Moin (2010:48) ada beberapa motif yang menjadikan perusahaan tertarik untuk melakukan merger dan akuisisi, yakni pertumbuhan atau diversifikasi yang tidak berisiko jika perusahaan mengeluarkan produk baru dan dapat mengurangi persaingan, menciptakan singergi operasional dan sinergi keuangan perusahaan, dan motif ekonomi di mana terjadi peningkatan pangsa pasar yang lebih besar.Hal ini disebabkan karena informasi tersebut akan mempengaruhi dari kinerja stuatu perusahaan sehingga menyebabkan pelaku pasar modal akan melakukan analisis. Pasar yang bereaksi positif terhadap notifikasi merger dan akuisisi adalah pasar yang efisien.

\section{Kinerja Keuangan Perusahaan}

Munawir (2007:3) mendefinisikan kinerja keuangan perusahaan sebagai tolok ukur prestasi yang diperoleh perusahaan dan merepresentasikan keadaan finansial dari suatu perusahaan dalam tempo tertentu. Kinerja Keuangan Perusahaan dapat dipergunakan sebagai tolak ukur keberhasilan dari merger dan akuisisi bagi suatu perusahaan. Analisis yang dimanfaatkan pada kinerja finansial perusahaan yakni rasio keuangan. Rasio Keuangan didapatkan dari hasil perbandingan suatu periode dengan periode tertentu berdasarkan pos-pos yang berada di dalam laporan keuangan.

Menurut Kasmir (2015:7), laporan yang merepresentasikan keadaan kesehatan finansial perusahaan di periode lampau atau dalam periode lain disebut laporan keuangan. Guna memahami kinerja finansial suatu perusahaan dibutuhkan analisis pada laporan keuangan perusahaan tersebut, menurut pendapat Brigham dan Houston (2014:78) mencakup (1) melakukan perbandingan dengan kinerja dari perusahaan perusahaan lain dalam lingkup industri yang sama dan (2) melakukan evaluasi kecondongan keadaan keuangan perusahaan selama periode yang ditentukan.

Kasmir (2015:104) menyatakan indikator yang menyatukan lebih dari satu angka perhitungan dan didapatkan menggunakan pembagian disebut rasio keuangan. Rasio keuangan berfungsi guna mengevaluasi kesehatan finansial suatu perusahaan dan kemampuan dari suatu perusahaan. Rasio keuangan yang dipergunakan untuk memperhitungkan kemampuan perusahaan pengakuisisi sebelum dan setelah melakukan akuisisi yakni rasio likuiditas, rasio solvabilitas, dan rasio profitabilitas.

\section{Rasio Likuiditas}

Rasio Likuditas yakni rasio yang dipergunakan untuk mengukur tingkat likuiditas perusahaan dalam memenuhi seluruh kewajiban janka pendeknya (Purwohandoko \& Asandimitra, 2006:30). Sedangkan menurut Brigham dan Houston (2014:134) rasio likuiditas yakni rasioyang menggambarkan hubungan antara kas dan aset lancar perusahaan lainnya dengan kewajiban lainnya. Rasio likiuditas yang digunakan dalam penelitian ini yaitu Current Ratio.

\section{Current Ratio (CR)}

Rasio lancar yakni menunjukkan sampai sejauh mana tagihan-tagihan jangka pendek dari para kreditor dapat dipenuhi dengan aktiva yang diharapkan akan dapat dikonversi menjadi uang tunai (Purwohandoko \& Asandimitra, 2006:30). Perhitungan CR dapat dilihat di rumus (1) (Purwohandoko \& Asandimitra, 2006:30).

$$
\text { Current Ratio }=\frac{\text { Current Assets }}{\text { Current Liabilities }} \times 100 \%
$$

\section{Rasio Solvabilitas}

Rasio solvabilitas atau biasa disebut financial leverage merupakan rasio yang digunakan untuk melihat sampai sejauh apa perusahaan menggunakan pendanaannya melalui utang (Brigham \& Houston, 2014:140). 


\section{Debt to Equity (DER)}

Menurut Kasmir (2015:112), Debt to Equity yaitu perbandingan yang dipergunakan guna mengevaluasi nilai kewajiban dibandingkan dengan modal. Perhitungan DER dapat dilihat di rumus (2) (Kasmir, 2015:112).

Debt to Equity $=\frac{\text { Total Utang }}{\text { Ekuitas }} \times 100 \%$

\section{Debt to Asset (DAR)}

Debt to Asset Ratio atau dikenal dengan Debt Ratio yakni rasio perbandingan antara total hutang dengan total aktiva yang digunakan mengukur presentase total dana yang disediakan kreditor. Indikasinya adalah semakin tinggi rasio, maka semakin tinggi risiko ketidak mampuan perusahaan melunasi seluruh hutangnya (Purwohandoko \& Asandimitra, 2006:32). Perhitungan DAR dapat dilihat di rumus (3) (Purwohandoko dan Asandimitra, 2006:32).

Debt to Asset $=\frac{\text { Total Debt }}{\text { Total Assets }} \times 100 \%$

\section{Rasio Profitabilitas}

Menurut Purwohandoko \& Asandimitra (2006:32), profitability ratio yakni rasio yang dipakai untuk mengukur kemampuan perusahaan menghasilkan keuntungan dalam periode tertentu. Sedangkan menurut Brigham \& Houston (2014:146), rasio profitabilitas merupakan sekelompok rasio yang menunjukkan kombinasi dari pengaruh likuiditas, manajemen aset, dan utang pada hasil operasi.

\section{Return on Equity (ROE)}

Menurut Purwohandoko \& Asandimitra (2006:33), rasio return on common equity atau dikenal dengan return on equity merupakan rasio perbandingan antara laba pajak dengan modal sendiri atau modalsaham yang digunakan untuk mengukur tingkat pengembalian atas investasi bagi pemegang saham biasa atau pemilik modal. Perhitungan ROE dapat dilihat di rumus (4) (Purwohandoko \& Asandimitra, 2006:33).

Return on Equity $=\frac{\text { EAT }}{\text { Common Equity }} \times 100 \%$

\section{Return on Asset (ROA)}

Return on total assets atau dapat disebut dengan Return on Asset ialah rasio perbandingan antara laba setelah pajak dengan total aktiva yang digunakan untuk mengukur kemampuan perusahaan dalam menghasilkan laba atas aktiva yang dipergunakan pada periode tertentu. Indikasinya bila ROA perusahaan dari tahun ke tahun mengalami peningkatan, maka perusahaan dapat dikatakan semakin efisien dalam mengelola bisnisnya dan sebaliknya (Purwohandoko \& Asandimitra, 2006:33. Perhitungan ROA dapat dilihat di rumus (5) (Purwohandoko \& Asandimitra, 2006:33).

Return on Asset $=\frac{E A T}{\text { Common Assets }} \times 100 \%$
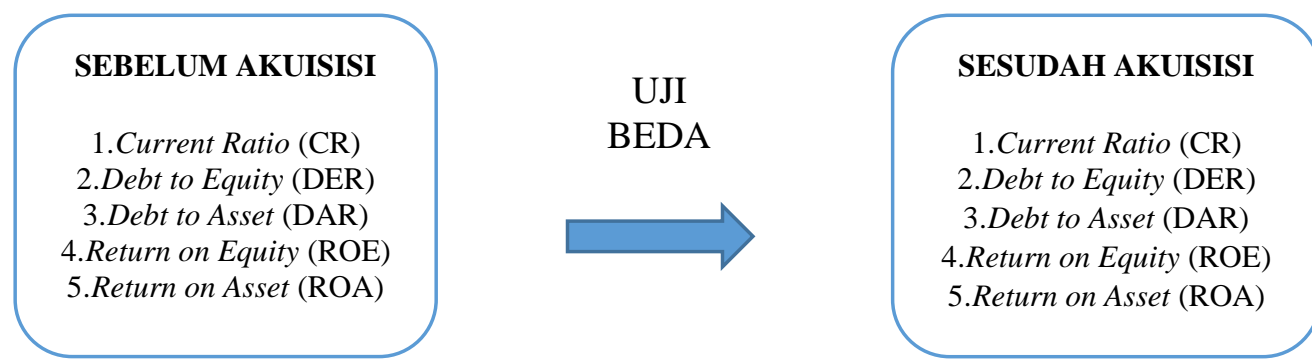

Gambar 2. KERANGKA KONSEPTUAL 
Angdriani Puspita Dewi \& Ulil Hartono. Analisis Perbandingan Kinerja Perusahaan Pengakuisisi Sebelum dan Sesudah Akuisisi Pada Tahun 2016

\section{Hubungan antar Variabel}

Berlandaskan teori yang telah dipaparkan beserta penelitian terdahulu, penelitian ini berfokus pada pengkajian perbedaan dari kinerja finansial akuisitor dilihat dari sebelum dan setelah perusahaan pengakuisisi melakukan akuisisi seperti yang dapat dilihat di Gambar 2.

Pada hasil pengkajian Nafilah \& Damayanti (2019:195), variabel current ratio mendapati penurunan di saat perusahaan mewujdukan merger dan akuisisi. Penurunan variabel dikarenakan terjadinya penurunan aktiva lancar yang belum seimbang dengan kenaikan utang lancar. Hasil pengkajian yang sama ditunjukkan juga pada penelitian Puteri \& Husaini (2019:210) mendapati penurunan Current Ratio perusahaan dibandingkan sebelum diakuisisi, namun penurunan tersebut tidak signifikan. Berbeda dengan hasil pengkajian Gunawan \& Sukartha (2013:280) yang menyebutkan bahwa terdapat penuruan likuiditas yang signifikan pada current ratio untuk periode 1 dan 2 tahun sesudah merger dan akuisisi disebabkan oleh peningkatan utang lancar yang tidak seimbang dengan aktiva lancar.

H1: Terdapat perbedaan kinerja perusahaan antara sebelum dan sesudah akuisisi yang diukur bedasarkan variabel current ratio.

Hasil kajian dari Nafilah \& Damayanti (2019:196) menyatakan nilai rasio debt to equity tidak didapati perbedaan setelah dilakukan uji hipotesis.Hasil kajian berbeda didapati dari Dewi \& Suryatini (2018:2243) yang menyatakan adanya perbedaan yang signifikan pada rata-rata debt to equity perusahaan sesudah akuisisi. Ukuran debt to equity bertambah karena perusahaan condong memanfaatkan hutang sebagai pendanaan asset perusahaan jika dikomparasikan dengan jumlah modal perusahaan yang dipergunakan,sehingga pada fluktuasi hutang seperti ini menggambarkan kondisi kesehatan keuangan perusahaan yag lebih berisiko.

H2: Terdapat perbedaan kinerja perusahaan antara sebelum dan sesudah akuisisi yang diukur berdasarkan variabel debt to equity.

Menurut Naziah et al. (2014:16), debt to asset pada perusahaan pengakuisisi membaik setelah menjalankan merger dan akuisisi karena debt to asset perusahaan pengakuisisi mendapati peningkatan signifikan. Sedangkan, Gunawan \& Sukartha (2013:288) mendapati adanya perbedaan debt to asset ratio antara sebelum dan sesudah merger dan akuisisi, di mana tingkat solvabilitas perusahaan menjadi lebih baik.

H3: Terdapat perbedaan kinerja perusahaan antara sebelum dan sesudah akuisisi yang diukur berdasarkan variabel debt to asset.

Pratiwi \& Sedana (2017:251) menemukan adanya kemajuan ROE untuk akuisitor setelah melaksanakan akuisisi dikarenakan adanya kemajuan earning before tax yang tinggi seimbang dengan kemajuan total equity milik perusahaan, namun setelah dilakukan uji hipotesis tidak didapati perbedaan secara signifikan pada rata-rata ROE sesudah akuisisi dibandingkan sebelum akuisisi. Berbeda dengan hasil penelitian Erlyene \& Musdholifah (2019:603), rasio return on equity perusahaan pengakuisisi mengalami penurunan dan memperlihatkan perbedaan signifikan.

H4: Terdapat perbedaan kinerja perusahaan antara sebelum dan sesudah akuisisi yang diukur berdasarkan variabel return on equity.

Nafilah \& Damayanti. (2019:199) menyatakan terdapat penurunan ROA setelah perusahaan mewujudkan akuisisi dan memperlihatkan perbedaan yang signifikan. Penurunan variabel ROA menunjukkan adanya ketidakberhasilan perusahaan dalam meningkatkan laba bersih. Hasil kajian yang sama juga dinyatakan Naziah, et al. (2014:13) yang mendapati perbedaan ROA sebelum dan sesudak akuisisi dan merger disebabkan usaha pengenalian bisnis dalam penerapan resiko yang lebih terstruktur yang dilakukan perusahaan lebih baik. Berbeda dengan hasil kajian Dewi \& Suryatini (2018:2342) yang tidak dapat membuktikan perbedaan yang signifikan pada variabel ROA. 
H5: Terdapat perbedaan kinerja perusahaan antara sebelum dan sesudah akuisisi yang diukur berdasarkan variabel return on asset.

\section{METODE PENELITIAN}

Penelitian ini menggunakan jenis penelitian komparatif. Sugiyono (2011:60) menyatakan penelitian komparatif merupakan penelitian di mana letak satu variabel atau lebih pada dua atau lebih sampel yang berbeda, atau pada saat periode yang berbeda dilakukan perbandingan. Model komparasi antara dua sampel yang dipergunakan dalam penelirian ini menggunakan sampel yang berkorelasi. Penelitian memanfaatkan jenis penelitian komparatif dikarenakan untuk mendapati perbedaan kemampuan finansial pada perusahaan pengakuisisi sebelum dan sesudah melakukan akuisisi pada periode 2016. Data yang dipergunakan yakni data sekunder berbentuk financial statements dan annual report dari perusahaan yang merujuk pada website milik perusahaan dan website milik Bursa Efek Indonesia, untuk list perusahaan yang melaksanakan merger dan akuisisi didapatkan dari www.kppu.go.id.

Populasi yang digunakan yakni perusahaan pengakuisisi dalam notifikasi merger \& akuisisi pada Komisi Pengawas Persaingan usaha (KPPU). Populasi penelitian mencakup dari perusahaan pengakuisisi tergabung di Bursa Efek Indonesia selama tahun 2016 sebanyak 65 kasus. Berdasarkan populasi yang digunakan, ditarik sampel dengan metode purposive sampling method sehingga diperoleh 12 perusahaan yang memenuhi kriteria-kriteria sampel.

Penelitian ini menetapkan standar kemampuan finansial yaitu perbandingan-perbandingan yang ditelaah menggunakan statistik parametrik maupun non-parametrik. Jika dalam pengujian data berdistribusi normal maka memanfaatkan uji parametrik yang dipergunakan yakni paired sample t-test, namun dalam pengujian yang belum berdistribusi normal memanfaatkan uji non-parametrik yakni uji Wilcoxon sign rank test (Fatimah, 2013:7).

\section{HASIL DAN PEMBAHASAN}

\section{Hasil Statistik Deksriptif}

Setelah melakukan perhitungan rasio keuangan perusahaan pengakuisisi dengan masa pengamatan 3 tahun sebelum akuisisi dan 3 tahun sesudah akuisisi, langkah berikutnya ialah melakukan analisis rasio keuangan. Analisis rasio keuangan merupakan metode perhitungan dan intepretasi rasio keuangan guna mengukur kinerja perusahaan. Rasio keuangan dapat dideskripsikan menggunakan statistik deskriptif sebagai gambaran dari suatu data yang ditinjau berdasarkan nilai minimum, nilai maksimum, nilai ratarata, standar deviasi, dan lain-lainnya (Ghozali, 2016:19). Berdasarkan hasil uji statistik desktiptif yang telah dilakukan menunjukkan bahwa rata-rata beberapa rasio keruangan perusahaan pengakuisisi mengalami kenaikan dan penurunan. Rata-rata variabel Current Ratio sebelum akuisisi lebih tinggi dibandingkan dengan rata-rata CR sesudah akuisisi. Rata-rata variabel Debt to Equity sebelum akuisisi lebih rendah dibandingkan dengan rata-rata DER sesudah akuisisi. Rata-rata variabel Debt to Asset sebelum akuisisi sebesar lebih rendah dibandingkan dengan rata-rata DAR sesudah akuisisi. Rata-rata variabel Return on Equity sebelum akuisisi lebih rendahdibandingkan dengan rata-rata ROE setelah akuisisi. Rata-rata Return on Asset sebelum akuisisi lebih rendah dibandingkan dengan rata-rata ROA sesudah akuisisi.

\section{Hasil Uji Normalitas}

Tahap berikutnya setelah menyelesaikan uji statisik deskriptif yakni dilakukannya uji normalitas dengan kolmogrof-smirnov test. Uji normalitas bermaksud mengukur kemungkinan dalam suatu model regresi variabel redisidual berdistribusi normal. Mempertimbangkan hasil uji normalitas dengan kolmogrof-sminorv test, data dari nilai rasio keuangan terdistribusi normal dan belum berdistribusi normal. Data untuk rasio keuangan pada variabel current ratio untuk tempo $2 \& 3$ tahun sebelum dan setelah akuisisi, variabel debt to equity untuk tempo 1, 2, dan 3 tahun sebelum dan setelah akuisisi, variabel return on equity untuk periode 1 tahun sebelum dan setelah akuisisi, return on asset untuk periode 2 tahun sebelum dan sesudah akuisisi berdistribusi tidak tampak normal dikarenakan taraf sig. 
Angdriani Puspita Dewi \& Ulil Hartono. Analisis Perbandingan Kinerja Perusahaan Pengakuisisi Sebelum dan Sesudah Akuisisi Pada Tahun 2016

dari hasil uji normalitasnya lebih rendah dari $a=0,05$, sehingga untuk data rasio keuangan tersebut memakai uji wilcoxon sign rank test. Sedangkan data untuk rasio keuangan pada variabel current ratio untuk tempo 1 tahun sebelum dan sesudah akuisisi, variabel debt to asset untuk tempo 1, 2, dan 3 tahun sebelum dan setelah akuisisi, return on equity untuk periode $2 \& 3$ tahun sebelum dan sesudah akuisisi, return on asset untuk periode $1 \& 3$ tahun sebelum dan setelah akuisisi terdistribusi normal dikarenakan taraf sig. $>\mathrm{a}=0,05$, maka untuk data rasio keuangan memakai uji paired sample t-test.

Tabel 1.

HASIL UJI NORMALITAS DATA RASIO KEUANGAN

\begin{tabular}{|c|c|c|}
\hline Periode & Variabel & Sig. \\
\hline \multirow{5}{*}{3 tahun sebelum akuisisi } & $\mathrm{CR}(\%)$ & 0,000 \\
\hline & $\operatorname{DER}(\%)$ & 0,150 \\
\hline & $\operatorname{DAR}(\%)$ & 0,200 \\
\hline & ROE $(\%)$ & 0,200 \\
\hline & $\operatorname{ROA}(\%)$ & 0,200 \\
\hline \multirow{5}{*}{2 tahun sebelum akuisisi } & $\mathrm{CR}(\%)$ & 0,200 \\
\hline & $\operatorname{DER}(\%)$ & 0,050 \\
\hline & DAR $(\%)$ & 0,200 \\
\hline & $\mathrm{ROE}(\%)$ & 0,200 \\
\hline & $\operatorname{ROA}(\%)$ & 0,200 \\
\hline \multirow{5}{*}{1 tahun sebelum akuisisi } & $\mathrm{CR}(\%)$ & 0,200 \\
\hline & $\operatorname{DER}(\%)$ & 0,000 \\
\hline & DAR $(\%)$ & 0,200 \\
\hline & ROE $(\%)$ & 0,000 \\
\hline & $\operatorname{ROA}(\%)$ & 0,200 \\
\hline \multirow{5}{*}{1 tahun sesudah akuisisi } & $\mathrm{CR}(\%)$ & 0,059 \\
\hline & $\operatorname{DER}(\%)$ & 0,000 \\
\hline & $\operatorname{DAR}(\%)$ & 0,200 \\
\hline & $\mathrm{ROE}(\%)$ & 0,001 \\
\hline & $\operatorname{ROA}(\%)$ & 0,130 \\
\hline \multirow{5}{*}{2 tahun sesudah akuisisi } & $\mathrm{CR}(\%)$ & 0,013 \\
\hline & $\operatorname{DER}(\%)$ & 0,011 \\
\hline & $\operatorname{DAR}(\%)$ & 0,200 \\
\hline & $\mathrm{ROE}(\%)$ & 0,200 \\
\hline & ROA $(\%)$ & 0,420 \\
\hline \multirow{5}{*}{3 tahun sesudah akuisisi } & $\mathrm{CR}(\%)$ & 0,000 \\
\hline & $\operatorname{DER}(\%)$ & 0,002 \\
\hline & $\operatorname{DAR}(\%)$ & 0,200 \\
\hline & ROE $(\%)$ & 0,057 \\
\hline & $\operatorname{ROA}(\%)$ & 0,200 \\
\hline
\end{tabular}

Sumber: Output SPSS (2020)

Tabel 2.

HASIL UJI PAIRED SAMPLE T-TEST

\begin{tabular}{ccccc}
\hline Periode & Variabel & t hitung & P value & Keterangan \\
\hline \multirow{2}{*}{1 tahun sebelum \& } & CR & $-0,472$ & 0,646 & Ha1 ditolak \\
sesudah akuisisi & DAR & $-1,004$ & 0,337 & Ha3 ditolak \\
2 tahun sebelum \& & ROA & $-1,211$ & 0,251 & Ha5 ditolak \\
sesudah akuisisi & DAR & $-1,364$ & 0,200 & Ha3 ditolak \\
3 tahun sebelum \& & ROE & $-2,073$ & 0,062 & Ha4 ditolak \\
sesudah akuisisi & DAR & $-4,200$ & 0,682 & Ha3ditolak \\
\cline { 2 - 5 } & ROE & $-0,844$ & 0,417 & Ha4 ditolak \\
\hline
\end{tabular}

Sumber: Output SPSS (2020) 


\section{Hasil Uji Hipotesis Paired Sample T-test}

Tahap berikutnya menjalankan uji hipotesis mempergunakan alat uji parametrik yakni paired sample $t$ test bagi data yang terdistribusi normal. Berdasarkan tabel 2, didapati bahwa hasil uji hipotesis mengahasilkan tingkat signifikansi $\mathrm{p}$ value $>0,05$ pada current ratio tempo satu tahun sebelum dan sesudah akuisisi, variabel debt to asset untuk tempo 1,2 dan 3 tahun sebelum dan sesudah akuisisi, variabel return on equity untuk periode $2 \& 3$ tahun sebelum dan setelah akuisisi, dan variabel return on asset untuk tempo $1 \& 3$ tahun sebelum dan setelah akuisisi, sehingga tidak didapati perbedaan signifikan.

\section{Hasil Uji Hipotesis Wilcoxon Sign Rank Test}

Saat perbandingan keuangan yang terdistribusi normal memanfaatkan alat uji non-parametrik dengan mempergunakan uji wilcoxon sign rank test.

Tabel 3.

HASIL UJI WILCOXON SIGN RANK TEST

\begin{tabular}{ccccc}
\hline Periode & Variabel & Z hitung & Asym Sig. & Keterangan \\
\hline 1 tahun sebelum \& & DER & $-0,78$ & 0,937 & Ha2 ditolak \\
sesudah akuisisi & ROE & 0,000 & 1,000 & Ha4 ditolak \\
2 tahun sebelum \& & CR & $-0,55$ & 0,583 & Ha1 ditolak \\
sesudah akuisisi & DER & $-1,216$ & 0,224 & Ha2 ditolak \\
3 tahun sebelum \& & ROA & $-0,892$ & 0,373 & Ha5 ditolak \\
sesudah akuisisi & CR & $-1,020$ & 0,308 & Ha1 ditolak \\
\hline
\end{tabular}

Sumber : Output SPSS (2020)

Pada tabel 3, nilai uji hipotesis mendapati tingkat signifikansi asym sig. > 0,05 untuk variabel current ratio untuk periode $2 \& 3$ tahun sebelum dan sesudah akuisisi, variabel debt to equity untuk tempo 1, 2 dan 3 tahun sebelum dan sesudah akuisisi, variabel return on equity untuk periode satu tahun sebelum dan setelah akuisisi, dan variabel return on asset untuk tempo 2 tahun sebelum dan setelah akuisisi, sehingga belum didapati adanya perbedaan yang terlihat signifikan.

\section{Perbedaan Current Ratio Sebelum \& Sesudah Akuisisi}

Berdasarkan hasil dari statistik deskriptif, menunjukkan Current Ratio perusahaan pengakuisisi mengalami penurunan dibandingkan sebelum perusahaan melakukan akuisisi. Penurunan current ratio disebabkan kenaikan aset lancar yang kurang seimbang antara penggunaan aset lancar oleh perusahaan agar memenuhi utang jangka pendek yang juga semakin meningkat. Namun penurunan current ratio tersebut belum meyankinkan ada perbedaan signifikan bagi kinerja keuangan perusahaan pengakuisisi.

Berdasarkan Tabel Uji Wilcoxon Sign Rank Test menunjukkan CR perusahaan pengakuisisi tidak berbeda secara signifikan dilihat dari tempo 3 tahun sebelum dan sesudah akuisisi dikarenakan taraf signifikansi CR lebih tinggi dari batas signifikansi maka Ha1 ditolak. Hasil tersebut diperkuat oleh hasil analisis current Ratio periode 2 tahun sebelum dan setelah akuisisi menggunakan uji wilcoxon sign rank test pada tabel 3 dan hasil current Ratio periode 1 tahun sebelum dan setelah akuisisi setelah mempergunakan uji paired sample t-test pada tabel 2.

Hasil ini sependapat dengan hasil penelitian dari Nafilah \& Damayanti (2019:195), berpendapat nilai rasio saat sebelum dan setelah merger atau akuisisi pada variabel CR belum tampak adanya perbedaan yang signifikan sesuai hasil uji hipotesis yang telah dikaji.

\section{Perbedaan Debt to Equity Sebelum \& Sesudah Akuisisi}

Hasil penelitian menunjukkan variabel DER perusahaan pengakuisisi mengalami kenaikan sebesar dibandingkan sebelum perusahaan melakukan akuisisi. Kenaikan rasio debt to equity ini disebabkan adanya penambahan total ekuitas yang tinggi diimbangi dengan penambahan total hutang yang tinggi setelah perusahaan melakukan akuisisi. Adanya kenaikan terhadap debt to equity tetap belum 
Angdriani Puspita Dewi \& Ulil Hartono. Analisis Perbandingan Kinerja Perusahaan Pengakuisisi Sebelum dan Sesudah Akuisisi Pada Tahun 2016

merepresentasikan adanya perbedaan tampak signifikan terhadap kinerja keuangan perusahaan pengakuisisi.

Hasil penelitian menunjukkan DER perusahaan akuisitor belum tampak perbedaan signifikan dilihat dari periode 3 tahun sebelum dan setelah akuisisi dikarenakan taraf signifikansi debt to equity melebihi dari signifikansi maka Ha2 ditolak. Hasil tersebut diperkuat dengan hasil analisis DER periode 1 dan 2 tahun sebelum dan setelah akuisisi mempergunakan uji wilcoxon sign rank test pada tabel 3 dengan taraf signifikansi.

Hasil ini searah dengan penelitian Puteri \& Husaini (2019:213) yang menyatakan rasio debt to equity yang diuji menggunakan wilcoxon sign rank test belum mengalami perbedaan signifikan sebelum dan setelah menjalankan akuisisi.

\section{Perbedaan Debt to Asset Ratio Sebelum \& Sesudah Akuisisi}

Berdasarkan hasil statistik deskriptif, memperlihatkan variabel Debt to Asset perusahaan pengakuisisi mengalami kenaikan sebesar dibandingkan sebelum perusahaan melakukan akuisisi. Kenaikan rasio debt to asset ini menandakan kemampuan perusahaan pengakuisisi setelah melakukan akuisisi kurang baik dikomparasikan sebelum melakukan akuisisi.

Pada Tabel 3, pengujian hipotesis menggunakan paired sample T-test menujukkan Debt to Asset perusahaan pengakuisisi tidak berbeda secara signifikan dilihat dari tempo 3 tahun sebelum dan setelah akuisisi dikarenakan taraf signifikansi debt to asset melebihi dari signifikansi maka Ha3 ditolak. Hasil tersebut dikuatkan dengan hasil analisis DAR periode 1 dan 2 tahun sebelum dan setelah akuisisi mempergunakan paired sample t-test pada tabel 2.

Hasil ini sependapat dengan penelitian milik Pratiwi \& Sedana (2017:256) yang mengemukakan bahwa kinerja keuangan perusahaan jika ditinjau dari rasio DAR, tidak meningkat secara signifikan.

\section{Perbedaan Return on Equity Ratio Sebelum \& Sesudah Akuisisi}

Berdasarkan hasil statistik deskriptif, merepresentasikan variabel Return on Equity perusahaan pengakuisisi tumbuh kenaikan dibandingkan sebelum perusahaan melakukan akuisisi. Peningkatan rasio return on equity menampakkan kapabilitas perusahaan pengakuisisi dalam mewujudkan laba bersih dilihat dari tingkat ekuitas yang diraih perusahaan cukup baik.

Berdasarkan Tabel 3 menunjukkan ROE perusahaan pengakuisisi tidak berbeda signifikan dilihat dari tempo 3 tahun sebelum dan setelah akuisisi dikarenakan taraf signifikansi return on equity melebihi dari signifikansi maka Ha4 ditolak. Hasil tersebut dikuatkan analisis ROE periode 2 tahun sebelum dan setelah akuisisi dan hasil ROE periode 1 tahun sebelum dan setelah akuisisi menggunakan wilcoxon sign rank test pada tabel 3 .

Hasil ini sepaham dengan penelitian yang dikerjakan Silaban \& Silalahi (2017:154), di mana penelitian tersebut menunjukkan belum ditemukan perbedaan signifikan pada rasio ROE perusahaan sebelum dan setelah merger dan akuisisi.

\section{Perbedaan Return on Asset Ratio Sebelum \& Sesudah Akuisisi}

Berdasarkan hasil statistik deskriptif, menggambarkan variabel ROA perusahaan pengakuisisi mengalami kenaikan dibandingkan sebelum perusahaan melakukan akuisisi. Peningkatan rasio return on asset menandakan kapabilitas perusahaan pengakuisisi dalam mendatangkan laba bersih ditinjau dari total aset yang dimiliki perusahaan cukup baik.

Tabel 2 menjelaskan ROA akuisitor belum memiliki perbedaan secara signifikan dilihat dari periode 3 tahun sebelum dan setelah akuisisi dikarenakan signifikansi return on asset lebih tinggi dari taraf signifikansi maka Ha5 ditolak. Hasil tersebut diperkuat dengan hasil analisis ROA periode 2 tahun sebelum dan setelah akuisisi menggunakan wilcoxon sign rank test pada tabel 3 dan hasil return on asset periode 1 tahun sebelum dan setelah akuisisi mempergunakan paired sample t-test pada tabel 2 . 
Hasil tersebut sependapat dengan penelitian yang dikaji Dewi \& Suryatini (2018:2342), yang menegaskan tidak didapatinya perbedaan signifikan pada rata-rata ROA pada akuisitor dibandingkan setelah melakukan akuisisi.

\section{KESIMPULAN}

Berlandaskan hasil penelitian yang dilakukan, maka dapat ditarik kesimpulan bahwa tidak ditemukan adanya perbedaan yang signifikan pada kinerja keuangan sebelum dan sesudah perusahaan melakukan akuisisi pada periode 2016. Kinerja keuangan dari perusahaan pengakuisisi yang ditelaah dengan rasio likuiditas (current ratio), rasio solvabillitas (debt to equity dan debt to asset), dan rasio profitabilitas (return on equity dan return on asset) tidak ditemui beda yang signifikan antara sebelum dan sesudah akuisisi tahun 2016 selama tempo peninjauan 3 tahun sebelum dan 3 tahun setelah perusahaan pengakuisisi melakukan akuisisi. Pengkajian hipotesis memanfaatkan uji paired samplet-test dan uji wilcoxon sign rank test secara serentak kurang dari taraf signifikan 0,05, sehingga hasil tersebut menolak hipotesis $\mathrm{Ha}$ 1,Ha2,Ha3,Ha4 dan Ha5. Hasil ini merepresentasikan akuisisi tidak selalu menghasilkan keberhasilan terhadap kinerja keuangan suatu perusahaan pengakuisisi secara signifikan. Penggunaan strategi bisnis dengan ekspansi perusahaan menggunakan merger dan akuisisi membutuhkan perencanaan dan pertimbangan dengan baik seperti melakukan analisis terhadap perusahaan target mulai dari kondisi perusahaan, kesesuaian visi dan misi perusahaan serta melihat kondisi ekonomi yang sedang terjadi.

Keterbatasan saat penelitian ini yakni periode pengamatan yang digunakan masih relatif pendek sebatas 3 tahun sebelum dan sesudah akuisisi, hingga belum mampu mengeneralisasikan dalam lingkup yang lebih luas. Penelitian selanjutnya dapat memperpanjang periode pengamatan sekaligus memperbanyak rasio keuangan yang dipergunakan menjadi variabel penelitian sehingga mampu menguatkan hasil penelitian \& memajukan generalisasi sesuai dengan kondisi nyata. Penelitian ini semata-mata menggunakan barometer kinerja keuangan perusahaan dan hanya fokus pada aspek ekonomi, penelitian selanjutnya diharapkan pula dapat mempergunakan indikator dari aspek non-ekonomi seperti proses penyusunan ulang yang akan dijalankan perusahaan pengakuisisi secara internal.

\section{DAFTAR PUSTAKA}

Brigham, E. F., \& Houston, J. F. (2009). Dasar-Dasar Manajemen Keuangan Edisi 10 Buku 1. Jakarta: Salemba Empat.

Brigham, E. F., \& Houston, J. F. (2014). Dasar-Dasar Manajemen Keuangan Edisi 11 Buku 1. Jakarta: Salemba Empat.

Cicilia, Sanny. (2017). Aksi merger dan akuisisi di Tanah Air meningkat. kontan.co.id. (https://industri.kontan.co.id/news/aksi-merger-dan-akuisisi-di-tanah-air-meningkat, diakses pada 15 Mei 2020)

Dewi, P. Y., \& Suryatini, N. P. (2018). Analisis Perbandingan Kinerja Keuangan Perusahaan Sebelum Dan Sesudah Akuisisi. E-Jurnal Manajemen Unud, 2323-2352.

Erlyene, P., \& Musdholifah. (2019). Analisis Komparatif Kinerja Keuangan Perusahaan Akuisitor Sebelum Dan Sesudah Akuisisi Yang Go Publik Antara 2011-2014. Jurnal Ilmu Manajemen (JIM), 594-605.

Fatimah, S. (2013). Analisis Perbedaan Kinerja Keuangan Sebelum dan Sesudah akuisisi (Pada perusahaan Publik yang terdaftar di bursa efek indonesia periode 2007-2009). Jurnal UMRAH, $1-18$. 
Angdriani Puspita Dewi \& Ulil Hartono. Analisis Perbandingan Kinerja Perusahaan Pengakuisisi Sebelum dan Sesudah Akuisisi Pada Tahun 2016

Ghozali, I. (2016). Aplikasi Analisis Multivariate dengan Program IBM SPSS 23. Semarang: BPFE Universitas Diponegoro.

Gunawan, K. H., \& Sukartha, I. M. (2013). Kinerja Pasar Dan Kinerja Keuangan Sesudah Merger Dan Akuisisi Di Bursa Efek Indonesia. E-Jurnal Akuntansi Universitas Udayana, 271-290.

Hartono, J. (2016). Teori Portofolio dan Analisis Investasi Edisi 10. Yogyakarta: BPFE-Yogyakarta.

Kamaludin K, S. K. (2015). Restrukturisasi, Merger \& Akuisisi. Bandung: CV Mandar.

Kasmir. (2015). Analisis Laporan Keuangan (Edisi 8). Jakarta: Kharisma Putra Utama Offset.

Kppu.go.id. 2019. Daftar Notifikasi Merger dan Akuisisi. (https://kppu.go.id/daftar-notifikasi-merger. Diakses pada 19 Juli 2020)

Lesmana, F. J., \& Gunardi, A. (2012). Perbedaan Kinerja Keuangan dan Abnormal Return Sebelum dan Sesudah Akuisisi di BEI. Jurnal Trikonomika, 195-211.

Mamduh, H., \& Halim, A. (2016). Analisis Laporan Keuangan Edisi Kelima. Yogyakarta: UPP STIM YKPN.

Moin, A. (2010). Merger, Akuisisi dan Divestasi (Edisi 2). Yogyakarta: Ekonesia.

Munawir, M. (2007). Analisa Laporan Keuangan. Yogyakarta: Liberty Yogyakarta.

Nafilah, A., \& Damayanti, C. R. (2019). Analisis Kinerja Keuangan Sebelum Dan Sesudah Perusahaan Melakukan Merger Dan Akuisisi (Studi Pada Perusahaan Yang Terdaftar Pada Bei Dan Melakukan Merger Dan Akuisisi Pada Periode 2012-2014). Jurnal Administrasi Bisnis (JAB), 192-201.

Naziah, U., Yusralaini, \& L, A. A. (2014). Analisis Perbandingan Kinerja Keuangan Perusahaan Sebelum Dan Sesudah Merger Dan Akuisisi Pada Perusahaan Manufaktur Yang Listing Di BEI 2009-2012. Jom Fekon, 1-18.

Ni'mah, N. F., \& Samryn, L. (2015). Analisis Perbandingan Kinerja Keuangan Perusahaan Sebelum dan Sesudah Merger dan Akuisisi. Jurnal Manajerial, 31-40.

Novaliza , P., \& Djajanti, A. (2013). Analisis Pengaruh Merger Dan Akuisisi Terhadap Kinerja Perusahaan Publik Di Indonesia (Periode 2004 - 2011). Jurnal Akuntansi \& Bisnis, 1-16.

Pratiwi, P. R., \& Sedana, I. P. (2017). Analisis Kinerja Keuangan Perusahaan Multinasional Sebelum Dan Sesudah Akuisisi (Studi Perusahaan Multinasional Pengakuisisi Di Bei). E-Jurnal Manajemen Unud, 235-263.

Purwohandoko, \& Asandimitra, N. (2006). Manajemen Keuangan I. Surabaya: Unesa University Press.

Puteri, L. P., \& Husaini, A. (2019). Analisis Perbandingan Kinerja Keuangan Perusahaansebelum Dan Sesudah Akuisisi (Studi Pada Perusahaan Sektor Property, Real Estate Dan Konstruksi Bangunan Yang Terdaftar Di Bursa Efek Indonesia Dan Melakukan Akuisisi Pada Tahun 2014). Jurnal Administrasi Bisnis (JAB), 206-215.

Silaban F.F, S. E. (2017). Analisis Perbandingan Kinerja Keuangan Akuisisi Yang Terdaftar Dibursa Efek Indonesia (Studi Pada Perusahaan Publik Tahun 2010-2013). Jurnal Reviu Akuntansi dan Keuangan (JRAK), 139-160.

Sitanggang, J. (2013). Manajemen Keuangan Perusahaan Lanjutan. Jakarta: Mitra Wacana Media. 
Suad Husnan, E. P. (2012). Dasar-Dasar Manajemen Keuangan (Edisi 6). Yogyakarta: UPP-AMP YKPN.

Sudana, I. M. (2011). Manajemen Keuangan Perusahaan Teori Dan Praktik. Jakarta. Jakarta: Erlangga.

Sugiyono, S. (2018). Metode Penelitian Kuantitatif, Kualitatif, dan $R \& D$ (Edisi 27). Bandung: Alfabeta. 